\title{
Syngas Treatment Unit for Small Scale Gasification - Application to IC Engine Gas Quality Requirement
}

\author{
L. C. Laurence ${ }^{\dagger}$ and D. Ashenafi \\ Ecole des Mines de Nantes, GEPEA UMR CNRS 61444 rue A. Kastler, BP 20277, 44307 Nantes Cedex 3, France
}

†Corresponding Author Email: laurence.le-coq@emn.fr

(Received July 16, 2010; accepted March 13, 2011)

\begin{abstract}
Gasification is a process that converts carbonaceous materials (coal, biomass, organic waste) into carbon monoxide and hydrogen by reacting the raw material at high temperatures with a controlled amount of oxygen and/or steam. The resulting gas mixture: syngas, can be used in energy production process. Syngas may be burned directly in internal combustion engines, used to produce methanol and hydrogen, or converted via the Fischer-Tropsch process into synthetic fuel. In addition, the high-temperature combustion refines out corrosive ash elements (chloride, potassium) allowing clean gas production after flying ash removal. Therefore, the main issue to syngas use in internal combustion engine is the removal of tarry product, ash and corrosive gaseous compounds. This paper consists in a state of the art on the composition of gaz from gazeifier considering the gasification operating conditions and the gazeified waste composition. The literature survey considers processes available to remove tarry products and particles from syngas produced in small scale gazeifier and to purify gas from unwanted gazeous compouds.
\end{abstract}

Keywords: Particle, Tar, Acid gas, Gas treatment.

\section{INTRODUCTION}

The conversion of biomass by gasification into a fuel suitable for use in a gas engine increases greatly the potential usefulness of biomass as a renewable resource. Power generation using a gas engine operating on gas produced by the gasification of biomass is applicable equally to both the developed and developing world as a means of reducing greenhouse gas emissions and replacing fossil fuel respectively.

Gasification is the conversion of biomass to a gaseous fuel by heating in a gasification medium such as air, oxygen or steam. Unlike combustion where oxidation is substantially complete in one process, gasification converts the intrinsic chemical energy of the carbon in the biomass into a combustible gas in two stages. The gas produced can then be standardised in its quality and is easier and more versatile to use than the original biomass e.g. it can be used to power gas engines and gas turbines, or used as a chemical feedstock to produce liquid fuels. Three product gas qualities can be produced from gasification by varying the gasifying agent, the method of operation and the process operating conditions. The main gasifying agent is usually air but oxygen/steam gasification and hydrogenation are also used. Catalytic steam gasification is another mode of operation that influences both the overall performance and efficiency. The three gas qualities have different calorific values $(\mathrm{CV})$, as shown in Table 1 (McKendry 2002).
Table 1 Calorific value of syngas according to gazifiing agent

\begin{tabular}{|lcc|}
\hline Low CV & $4-6 \mathrm{MJ} / \mathrm{Nm}^{3}$ & Using air, steam/air \\
\hline Medium CV & $12-18 \mathrm{MJ}^{3} \mathrm{Nm}^{3} \quad$ Using $\mathrm{O}_{2}$, steam \\
\hline High $\mathrm{CV}$ & $40 \mathrm{MJ} / \mathrm{Nm}^{3}$ & Using $\mathrm{H}_{2}$, hydrogenation \\
\hline
\end{tabular}

Low CV gas is used directly in combustion or as an engine fuel, while medium/high $\mathrm{CV}$ gases can be utilized as feedstock for subsequent conversion into basic chemicals: principally methane and methanol. As the use of oxygen for gasification is expensive, air is normally used for processes up to about $50 \mathrm{MW}$.The disadvantage is that the nitrogen introduced with the air dilutes the producted gas, giving gas with a net $\mathrm{CV}$ of 4-6 MJ/Nm3 (compared with natural gas at 36 $\mathrm{MJ} / \mathrm{Nm} 3)$. Gasification with oxygen gives a gas with a net $\mathrm{CV}$ of $10-15 \mathrm{MJ} / \mathrm{Nm} 3$ and with steam, 13-20 $\mathrm{MJ} / \mathrm{Nm} 3$. It can be seen that while a range of product gas qualities can be produced, economic factors are a primary consideration.

There are various technologies used for synthesis gas cleaning depending on the specific clean up requirements. In that paper, the clean up technologies are discussed regarding syngas feed to an IC engine. In that case, the gas cleanup depends on the composition of the syngas, the gas flowrate (depending on gasifier size, the gas requirement for use in IC engine and economic considerations. Indeed, economic and energetic costs are one of the key factors to choose and design the gas cleaning process especially fo small 
scale of gazifiers which must have a low cost and robust gas treatment system to be competitive.

\section{CONTEXT}

\subsection{Types of Gasifiers}

Based on the type of contact between the oxidizing agent and the fuel, biomass gasifiers can be broadly classified in to fixed bed, fluidized bed and entrained flow gasifier. All these technologies can be operated at ambient or higher pressure for the thermo-chemical conversion of biomass. The gasification medium (air, pure oxygen or water vapour) participates in the partial oxidation and reduction reaction to generate synthesis gas along with drying and pyrolysis. Fixed bed gasifier has been the traditional process used for gasification and is operated at temperatures around $1000^{\circ} \mathrm{C}$. Fresh biomass is fed from the top of the reactor through an opening on the reactor head and sinks downward slowly by gravity as conversion of fuel proceeds. Fixed bed gasifiers are classified as up draft and down draft depending on the direction of air flow. Fluidized bed biomass gasifiers operate with a fluidized mixture of the bed material and biomass. The bed material can be inert (quartz sand) or catalytically active (dolomite or olivine).The fluidized bed can be in bubbling or circulating mode depending on the degree of fluidization.

In entrained flow gasifiers, a fine grained solid whose size is smaller than $10 \mu \mathrm{m}$ is carried through the reactor by the gasification medium and is gasified. Gasification takes place at a temperature between 1200 and $1500^{\circ} \mathrm{C}$ (Lettner et al. 2007). This high temperature ensures complete conversion of the hydrocarbon compounds resulting from pyrolysis. Pyrolysis and gasification take place at the same time in this type of gasifier. The melted ash is removed as liquid and the tar content is very low due to the high temperature. Entrained flow gasifiers could be classified as slagging and nonslagging depending on the way the ash melts and flows in the reactor. In slagging gasifiers, the ash melts in the gasifier, flow down the walls and leave the reactor as a liquid slag. But the walls are kept free of slag in the case of non-slagging gasifier.

\subsection{Composition of biomass synthesis gas}

The gasification/pyrolysis process for producing syngas is regarded as one of the most promising options for utilizing biomass. The syngas from biomass is not only directly used in gas turbine and engines for power generation; it can also be catalytically converted into methanol, dimethyl ether, Fischer-Tropsch oils or other chemical products. In the gasification/pyrolysis process, with exception of generating useful products, many by products such as fly ash, NOx, SO2 and tar are also formed. Tar derived from biomass gasification or pyrolysis will be condensed as temperature is lower than its dew point, then block and foul process equipments like fuel lines, filters, engines and turbines. It was reported that tar content in the syngas from an air-blown circulating fluidized bed (CFB) biomass gasifier was about $10 \mathrm{~g} / \mathrm{m} 3$. For other types of gasifier, tar content varied from about 0.5 to $100 \mathrm{~g} / \mathrm{m} 3$ (Han and
Kim 2006). Besides the operational parameters, the composition of syngas also depends on the type of gasifying agent used and the type of gasifier. Syngas produced using steam as gasifying agent contains much less percentage of $\mathrm{N} 2$ around 3\% compared to the $41 \%$ $\mathrm{N} 2$ in a syngas produced when air is used as a gasifying agent (Ahrenfeld, 2007). Also depending on the design of the gasifier and the type of biomass used as fuel, there will be more or less of the components mentioned above. In gasification, tars are formed during the pyrolysis process which initiates at about $230^{\circ} \mathrm{C}$, where the complex polymers in the biomass are broken down resulting in a gas consisting mainly of $\mathrm{CO} 2, \mathrm{H} 2 \mathrm{O}, \mathrm{CH} 4$, $\mathrm{CO}, \mathrm{H} 2$, tar and char (Table 2). The amount of tars is much higher in counter-current than in co-current gasifiers. For IC engine applications, counter-current gasifiers are therefore not considered as an option.

Table 2 Gas quality of raw producer gas from atmospheric, air blown biomass gasifiers (Hasler \& Nussbaumer 1999).

\begin{tabular}{|c|c|c|c|c|}
\hline Component & Unit & $\begin{array}{l}\text { Fixed } \\
\text { bed co- } \\
\text { current } \\
\text { gasifier }\end{array}$ & $\begin{array}{l}\text { Fixed } \\
\text { bed } \\
\text { counter- } \\
\text { current } \\
\text { gasifier }\end{array}$ & $\begin{array}{l}\text { CFB } \\
\text { gasifier }\end{array}$ \\
\hline $\begin{array}{l}\text { Fuel } \\
\text { moisture }\end{array}$ & $\% \mathrm{mf}$ & $6-25$ & $\mathrm{Nd}$ & $13-20$ \\
\hline Particles & $\mathrm{mg} / \mathrm{Nm}^{3}$ & $\begin{array}{l}100- \\
8000 \\
\end{array}$ & $\begin{array}{l}100- \\
3000 \\
\end{array}$ & $\begin{array}{l}8000- \\
100,000\end{array}$ \\
\hline $\begin{array}{l}\text { Tar range } \\
\text { (mean) }\end{array}$ & $\begin{array}{l}\mathrm{mg} / \mathrm{Nm}^{3} \\
\left(\mathrm{~g} / \mathrm{m}^{3}\right)\end{array}$ & $\begin{array}{l}10- \\
6000 \\
(0.5) \\
\end{array}$ & $\begin{array}{l}10,000- \\
150,000 \\
(50)\end{array}$ & $\begin{array}{l}2000- \\
30,000 \\
(8)\end{array}$ \\
\hline LHV & $\mathrm{MJ} / \mathrm{Nm}^{3}$ & $4.0-5.6$ & $3.7-5.1$ & $3.6-5.9$ \\
\hline $\mathrm{H}_{2}$ & Vol. \% & $15-21$ & $10-14$ & $15-22$ \\
\hline $\mathrm{CO}$ & Vol. \% & $10-22$ & $15-20$ & $13-15$ \\
\hline $\mathrm{CO}_{2}$ & Vol. \% & $11-13$ & $8-10$ & $13-15$ \\
\hline $\mathrm{CH}_{4}$ & Vol. \% & $1-5$ & $2-3$ & $2-4$ \\
\hline $\mathrm{C}_{\mathrm{n}} \mathrm{H}_{\mathrm{m}}$ & Vol. \% & $0.5-2$ & $\mathrm{Nd}$ & $0.1-1.2$ \\
\hline $\mathrm{N}_{2}$ & Vol. \% & rest & rest & rest \\
\hline
\end{tabular}

State-of-the-art co-current gasifiers exhibit a tar level of less than $1000 \mathrm{mg} / \mathrm{Nm} 3$ (Hasler \& Nussbaumer 1999). CFB gasifiers exhibit very high particle contents and moderate to high tar levels in the producer gas.

According to the analysis made by Hasler \& Nussbaumer (1999), measurements of the particle size distributions from two different fixed bed gasifiers showed bimodal size distributions with maxima $<1.5$ $\mu \mathrm{m}$ and $>5 \mu \mathrm{m}$. In both gasifiers, the mass of particles with an aerodynamic diameter $<1.5 \mu \mathrm{m}$ represents more than $60 \mathrm{mg} / \mathrm{Nm} 3$. However most applications of producted gases like internal combustion engines require low tar content, of the order $100 \mathrm{mg} / \mathrm{Nm} 3$ or less, and particulate matter of less than $50 \mathrm{mg} / \mathrm{Nm} 3$. Hence, tar and particulate matter disposal becomes one of the most necessary and urgent problems during biomass gasification for internal combustion engine application.

\subsection{Applications of biomass synthesis gas}

Solid biomass undergoes thermal decomposition at temperatures of approximately $600-1000^{\circ} \mathrm{C}$ to form synthesis gas that contains $\mathrm{H} 2, \mathrm{CO}, \mathrm{CO} 2, \mathrm{CH} 4, \mathrm{H} 2 \mathrm{O}$ and other gaseous hydrocarbons. Solid char and tar 
which is liquid at room temperature are also formed during this process. The solid phase has a carbon content higher than $76 \%$ which enables it to be used directly for industrial purpose (Balat et al. 2009). The gaseous product (synthesis gas) can be burnt to generate heat or electricity, used in the synthesis of liquid transportation fuels, $\mathrm{H} 2$ or other chemicals. The liquid product can be used as fuel in boilers, gas turbines or diesel engines (Balat et al. 2009). The following Fig. 1 shows the various products obtained from a biomass synthesis gas.

But the main purpose of biomass gasification is the production of low or medium heating value gas which can be used as fuel in an IC engine for power production as shown in Fig. 2 (Po 2001). Synthesis gas from biomass gasifier is being implemented predominantly in combustion engines. This is due to the high power density of the engine generator heat extraction system with high degree of electrical and overall efficiency. The life time of the plant depends on the constancy of the gas quality and the various gas control and treatment facilities.

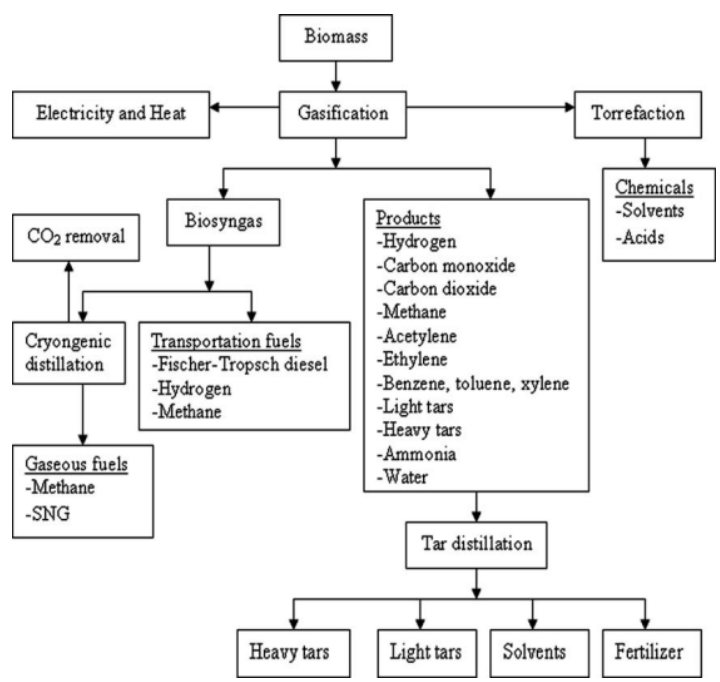

Fig. 1. Various products of biomass synthesis gas (Balat et al. 2009)

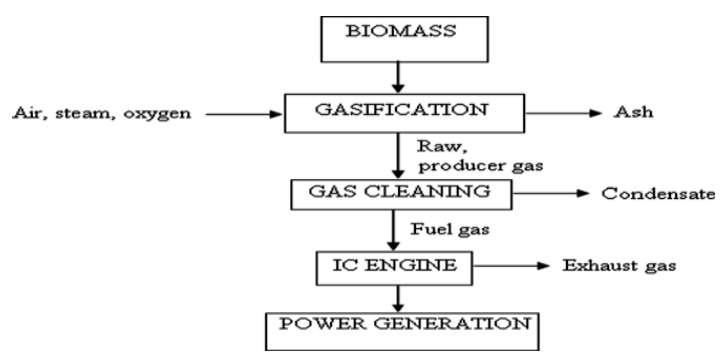

Fig. 2. application of biomass synthesis gas in an IC engine

\subsection{Biomass synthesis gas quality requirement for internal combustion engines}

Biomass has currently got considerable attention as a potential substitute for fossil fuels in heat and power generation. It helps for a reduction in environmental impact and offers interesting solution to waste disposal.
But the presence of by products in the synthesis gas makes it necessary to clean the gaseous fuel before its use in any power generator, although IC engines are considered to be more tolerant to contaminants than gas turbines. According to a work by Baratieri et al. (2009), it is possible to have a tar content of up to 50$100 \mathrm{mg} / \mathrm{Nm} 3$ in the produced gas. Alkali particularly $\mathrm{Na}$ and $\mathrm{K}$ in the biomass ashes and sulphur compounds have the most deleterious effect on gas turbines by corroding the blades. Particulate matters such as char and ash also have a damaging effect on any moving part. The tar condensable phase causes fouling in the piping system and heat exchangers and will be a potential problem if the synthesis gas has to be compressed. But gas turbines are less sensitive to tar than IC engines as the gas temperature is usually high and tars are in vapour form.

According to the analysis made by Hasler \& Nussbaumer (1999), co-current small scale atmospheric fixed bed gasifiers exhibit a particle level in the range $50 \mathrm{mg} / \mathrm{Nm}^{3}$ to $500 \mathrm{mg} / \mathrm{Nm}^{3}$ where as the concentration of high boiling tar components ranges from $50 \mathrm{mg} / \mathrm{Nm}^{3}$ to $1000 \mathrm{mg} / \mathrm{Nm}^{3}$. But for satisfactory IC engine operation, the acceptable particulate and tar concentrations are $<50 \mathrm{mg} / \mathrm{Nm}^{3}$ and $<100 \mathrm{mg} / \mathrm{Nm}^{3}$ respectively (Hasler \& Nussbaumer 1999). The following Table 3 shows typical typical values of gas quality requirements for power generators.

Table 3 Gas quality requirement for power generators (Hasler \& Nussbaumer 1999)

\begin{tabular}{|l|l|l|l|l|}
\hline Component & Unit & $\begin{array}{l}\text { Ic } \\
\text { engine }\end{array}$ & $\begin{array}{l}\text { Gas } \\
\text { turbine }\end{array}$ & $\begin{array}{l}\text { Methanol } \\
\text { synthesis }\end{array}$ \\
\hline Particles & $\mathrm{mg} / \mathrm{Nm}^{3}$ & $<50$ & $<30$ & $<0.02$ \\
\hline $\begin{array}{l}\text { Particle } \\
\text { size }\end{array}$ & $\mu \mathrm{m}$ & $<10$ & $<5$ & \\
\hline Tar & $\mathrm{mg} / \mathrm{Nm}^{3}$ & $<100$ & & $<0.1$ \\
\hline Alkali & $\mathrm{mg} / \mathrm{Nm}^{3}$ & & 0.24 & \\
\hline $\mathrm{NH} 3$ & $\mathrm{mg} / \mathrm{Nm}^{3}$ & & & $<0.1$ \\
\hline $\begin{array}{l}\mathrm{H} 2 \mathrm{~S} \& \\
\mathrm{COS}\end{array}$ & $\mathrm{mg} / \mathrm{Nm}^{3}$ & & & $<1$ \\
\hline $\mathrm{Cl}$ & $\mathrm{mg} / \mathrm{Nm}^{3}$ & & & $<0.1$ \\
\hline $\mathrm{CO} 2$ & $\mathrm{Vol} \%$ & $\begin{array}{l}\text { No } \\
\text { limit }\end{array}$ & $\begin{array}{l}\text { No } \\
\text { limit }\end{array}$ & $<12$ \\
\hline
\end{tabular}

Table 4 Acceptable and preferable producer gas specifications for modern engines (Knoef 2000)

\begin{tabular}{|l|l|l|}
\hline Parameter & Acceptable & Prefrable \\
\hline Dust content & $<50$ & $<5$ \\
\hline Particle size & $<10$ & $<1$ \\
\hline Tar content & $<100$ & $<50$ \\
\hline Gas heating value $\left(\mathrm{KJ} / \mathrm{Nm}^{3}\right)$ & $>2500$ & $>4200$ \\
\hline
\end{tabular}

Therefore gas cleaning systems are required to reduce contaminants (particulate matter, tar and some other impurities) from the raw synthesis gas level to the IC engine requirement level (Table 4) and this will be the main concern of this paper. Gas cleaning is a general term for removing the unwanted impurities from biomass gasification product gas and generally involves an integrated, multi-step approach that depends on the end use of the product gas. For the purpose of this paper, the focus will be on removing or eliminating particulates and tars without regard to acid gas, ammonia and alkali metal since those are not of a great 
concern for IC engine application. The following sections will deal with gas cleaning and the various technologies available for this.

\section{Biomass Synthesis Gas Cleaning}

There are various technologies used for synthesis gas cleaning depending on the specific clean up requirements. The clean up required for syngas that will be fed to an IC engine is much less than that required for chemical synthesis. Therefore the gas cleanup unit for a system is generally determined by the composition of the syngas exiting the gasifier, the clean up requirement for the intended use and economic considerations and this will be dealt with in detail in the technology selection and flow sheet development section.

\subsection{Particulate removal}

During gasification, the mineral matter in the biomass feedstock will form inorganic ash and the unconverted biomass will form char. The concentration of these particulates in the product synthesis gas is often influenced by the gasifier design. The fixed bed gasifiers generally produce lower particulate load than fluidized bed gasifiers and these particulate emissions can cause abrasion to downstream equipment or present emission problems. Therefore, it will be mandatory to remove these particulates before using the gas in any downstream process.

The technologies currently used for particulate removal could be broadly classified in to dry gas cleaning or dry gas collectors like cyclone separators, barrier filters, electrostatic precipitators and wet gas cleaning or wet scrubbers (spray towers, cyclone spray scrubbers, venturi scrubbers and packed bed scrubbers). Tar condensation during this particulate removal can be avoided by maintaining the synthesis gas temperature above the tar dew point.

Dry gas cleaning can be divided in to hot gas cleaning with heat resistant filter at gas temperature above $500^{\circ} \mathrm{C}$ and dry gas cleaning in fabric filters below $200^{\circ} \mathrm{C}$. Hot gas cleaning is important for gas utilization at high temperatures (gas turbine and fuel cells) and to lower the particulate load in the heat exchangers during cooling. Dry gas cleaning at lower temperature (below $200^{\circ} \mathrm{C}$ ) is mostly used for low temperature synthesis gas application like internal combustion engine which is the main concern of this paper.

Wet gas cleaning is purification of synthesis gas by means of a liquid scrubbing agent in a suitable scrubber system. The cleaning is the result of the adherence and dissolving property of the contaminants in the liquid. These cleaning methods also have a cooling effect because of the heat exchange between the syngas and the scrubbing liquid. Scrubbing liquids that are commonly used are water, Water/oil emulsion, condensates and various hydrocarbons. Particulates with diameter between 0.1 and $1 \mu \mathrm{m}$ are the most difficult to capture either by diffusion or inertial mechanism. They are too large to diffuse well and too small to settle (Reed \& Das 2007). Wetted particles tend to stick together better when they collide thereby assisting agglomeration. Wet scrubbers are used widely especially in stationary applications for cleaning and cooling the gas. The most commonly used wet scrubbers are spray towers, cyclone spray scrubbers, sieve plate scrubbers, venturi scrubbers and packed bed scrubbers.

\subsection{Tar Removal}

The product gas from biomass gasification contains organic impurities (tar), inorganic impurities and particulate matter in addition to the main components $\mathrm{CO}, \mathrm{H} 2, \mathrm{CO} 2, \mathrm{CH} 4, \mathrm{H} 2 \mathrm{O}$ and $\mathrm{N} 2$. The organic impurities range from low molecular weight hydrocarbons to high molecular weight poly nuclear aromatic hydrocarbons. The lower molecular weight components can be used as fuel in gas turbines or engines. But the higher molecular weight hydrocarbons (tar) can condense or polymerize to more complex structures in exit pipes, heat exchangers or particulate filters. This can cause chocking and attrition which results in decrease of efficiency and increase in the cost of the process.

Since the organic impurities contain a wide range of compounds, it will be necessary to define tars to identify them from the lower molecular weight hydrocarbons. A meeting was held in March 1998 in Brussels by the members of the gasification task of the IEA Bioenergy (US DOE and DGXVII of the European commission) to address this issue. Two sampling and analysis protocols were developed in this meeting for small scale fixed bed engine based systems and larger utility scale plants. It was also decided to define tars as hydrocarbons with molecular weight higher than benzene (Maniatis \& Beenackers 2000). So this definition will be used throughout this paper to define tars.

The current state of the art tar removal technologies could be broadly classified in to five groups as mechanism methods (cyclone, filters, granular beds, RPS, electrostatic precipitators and scrubbers), self modification (using a low tar gasifier or optimum operating parameter), catalytic cracking, thermal cracking and plasma methods (Pyroarc, corona, glidarc).

Mechanism methods including scrubber, filter, cyclone and electrostatic precipitators are primarily used to capture particles. But they are also considerably efficient in removing tars, as can be seen in Table 5. Tar removal efficiencies of 51 to $91 \%$ were obtained in a venturi scrubber for a counter-current rice husk gasifier (Hasler 1997). According to Janssen and his colleagues, tar level down to $20-40 \mathrm{mg} / \mathrm{m} 3$ and particulate level down to $10-20 \mathrm{mg} / \mathrm{m} 3$ can be achieved with a water scrubber (Jansens et al. 2002). But these systems are fairly expensive, generate a lot of contaminated water and energy in the tar is lost. Rotary particle separator (RPS) was used in Energy research Centre of the Netherlands (ECN) to remove tar although it was not satisfactory. But OLGA system (oil based gas washer) was successfully demonstrated in a laboratory scale gasifier in ECN and heavy tars were completely 
removed. This resulted in a tar dew point lower than $25^{\circ} \mathrm{C}$ (Boerrigter 2005).

Table 5 Tar and particle removal efficiency of some mechanism methods (Han \& Kim 2008)

\begin{tabular}{|l|l|l|}
\hline Method & $\begin{array}{l}\text { Particle removal } \\
(\%)\end{array}$ & $\begin{array}{l}\text { Tar } \\
\text { removal } \\
(\%)\end{array}$ \\
\hline Sand bed filter & $70-99$ & $50-97$ \\
\hline Wash tower & $60-98$ & $10-25$ \\
\hline Venturi scrubber & & $50-90$ \\
\hline $\begin{array}{l}\text { Wet electrostatic } \\
\text { precipitator }\end{array}$ & $>99$ & $0-60$ \\
\hline Fabric filter & $70-95$ & $0-50$ \\
\hline $\begin{array}{l}\text { Rotational particle } \\
\text { separator }\end{array}$ & $85-90$ & $30-70$ \\
\hline $\begin{array}{l}\text { Fixed bed tar } \\
\text { adsorber }\end{array}$ & & 50 \\
\hline
\end{tabular}

Electrostatic precipitators have shown more than $99 \%$ dust and 40-70\% tar removal according to experiments done on an updraft gasifier on Harboore, down draft gasifier at Weiner Weustadt and CFB gasifier at ECN (Poasen \& Rabou 2004). The previous Table 5 shows the tar and particle reduction efficiency of various mechanism methods.

The self modification method is based on optimizing the operating parameters temperature, equivalence ratio, type of biomass, pressure, gasifying medium and residence time in order to decrease the tar content. As the temperature increases beyond $600^{\circ} \mathrm{C}$, the tar yield will generally decrease due to tar cracking at higher temperature. This was confirmed by experimental works of Narvapaez (1996) and $\mathrm{Li}$ et al. (2004). Navarpaez found that the tar content at 700 and $800^{\circ} \mathrm{C}$ were 19 and $5 \mathrm{~g} / \mathrm{Nm} 3$ and $\mathrm{Li}$ observed that tar yield decreased from 15 to $0.54 \mathrm{~g} / \mathrm{Nm} 3$ when the temperature is increased from 970 to $1090 \mathrm{~K}$. Increase in the equivalent ratio will also decrease the amount of tar although the heat value of the gas decreases. The relation between the type of biomass and the tar yield was also investigated by different researchers. Among them was Kosstrin (1980) who observed 35\% tar yield for wood, $60 \%$ for paper and only $30 \%$ for sawdust in his experimental work.

Devnir observed the relation between steam and tar yield in his simulation work and concluded that tar conversion increases with an increase in the amount of steam. In addition of affecting the tar yield, operating parameters also influence the tar properties. Morf observed the influence of the type of gasifier on the tar yield as shown in the Table 6 below.

Table 6 Tar yield in different type of gasifiers

\begin{tabular}{|l|l|l|l|l|}
\hline & \multicolumn{2}{|c|}{ Fixed bed } & \multicolumn{2}{c|}{ Fluidized bed } \\
\cline { 2 - 5 } & $\begin{array}{l}\text { Counter } \\
\text { current }\end{array}$ & $\begin{array}{c}\text { Co } \\
\text { current }\end{array}$ & Bubbling & Circulating \\
\hline $\begin{array}{l}\text { Mean tar } \\
\text { yield } \\
\left(\mathrm{mg} / \mathrm{Nm}^{3}\right)\end{array}$ & 50 & 0.5 & 12 & 8 \\
\hline $\begin{array}{l}\text { Tar range } \\
\left(\mathrm{mg} / \mathrm{Nm}^{3}\right)\end{array}$ & $10-150$ & $0.01-6$ & $1-23$ & $1-30$ \\
\hline
\end{tabular}

Therefore, it is possible to decrease the tar content in the synthesis gas by optimizing the operating parameter parameters of the gasifier as shown in the above observation. But this might not be the case while designing a cleaning process for an already designed gasifier which is the concern of this paper.

Thermal Cracking is based on the fact that tar molecules can be cracked to lighter gases when the raw gas from gasification is heated to higher temperatures. According to the analysis done by Bridgewater, biomass derived tar is very refractory and hard to crack by thermal treatment alone. So he suggested increasing residence time, using a fluidized bed reactor free board, direct contacting with a hot surface although this decreased the overall efficiency (Bridgewater 1995). Manuatis and Beenackers (2000) concluded from their experimental work that the preferable tar content in gases for engine applications is below $50 \mathrm{mg} / \mathrm{Nm} 3$ and this was obtained at $1250^{\circ} \mathrm{C}$ (Xiaohui 2003) which is not still economical attractive for a small scale gasifier in addition to the biomass tar being difficult to crack.

Catalytic cracking coverts tar in to useful gases and adjust the composition of the product gas. According to the US national renewable energy laboratory 2002 report, three groups of catalyst materials have been used in biomass gasification. These are alkali metals, Nonmetallic oxides and supported metallic oxides. Alkali metals are considered as primary catalysts since they enhance the biomass gasification reactions rather than tar reforming. They are directly mixed with the biomass when they are fed to the reactor and enhance char formation reactions during thermo chemical conversion (Richards and Zhange 1991). They give poor carbon conversion, increased ash content and difficult to recover. This makes them unattractive for commercial use.

The non-metallic and supported metallic oxide catalysts are referred to as secondary catalysts since they are located in a separated fixed bed reactor downstream of the gasifier. The most widely studied non-metallic catalysts are Dolomites (calcium magnesium carbonates). Dolomites are relatively cheap and are considered as disposable. Tar conversion efficiency is high when dolomites are operated at high temperatures $\left(900^{\circ} \mathrm{C}\right)$ with steam. Biomass gasification tar reforming with supported $\mathrm{Ni}$ based catalysts has also been extensively demonstrated. Hot gas conditioning using catalysts offers the best solution for mitigating biomass gasification tars. The best currently available tar reforming process consists of calcined dolomite bed followed by a fixed bed $\mathrm{Ni}$ catalyst reforming reactor operating at about $800^{\circ} \mathrm{C}$ (Dayton 2002). But catalytic cracking will not be discussed in more detail here since it is not economically attractive for small scale gasifiers.

Catalytic and thermal cracking processes involve creation and stabilization of active species which there after initiates the necessary reactions. The same thing happens in plasma methods where similar species can be created by energetic electron-molecule collisions. The current development level of this method demands $20 \%$ of the final electrical output from the biomass gasification for gas cleaning which is far from being 
economically attractive even for large scale power plants. It is also still on research level to decrease the power requirement to 5\% (Nair et al. 2003).

III.3. Process selection and flow sheet development Synthesis gas cleaning is a crucial step in an IC engine integrated biomass gasification systems. This cleaning as explained in the previous sections is required to remove tars, particulates and other trace impurities from the synthesis gas. So the main objective of this section is to select an appropriate process for cleaning the synthesis gas from a small scale fixed bed gasifier for an IC engine application. As it is shown in the synthesis gas quality requirement Table 3 , the main parameters to be considered for this selection will be particulate matter concentration, particle size and tar concentration. The other trace impurities are not of a great concern for an IC engine application although they are also removed in the process. The major criterions used for this selection are the operating conditions of the given equipment or unit, its removal efficiency and the capital investment required. The capital investment criterion is very important here since the gas cleaning equipment is going to be designed for a small scale gasifier.

\subsubsection{Based on Operating condition}

Cyclone, fabric filters, ceramic filter, granular bed filters and dry and wet electrostatic precipitators are commonly used for particulate removal although they are also applied for tar removal. The operating temperature for gases containing both particulate and tar should be either above the tar dew point or particles and tar should be removed simultaneously in scrubbers (Table 7). The tar dew point is usually in the range of $375-400^{\circ} \mathrm{C}$ according to the analysis given in the US National renewable energy laboratory 2006 report. Fabric filters have operating temperature between 60$250^{\circ} \mathrm{C}$ and are thus not suitable for this purpose. Dry electrostatic precipitators are also not recommended for biomass syngas cleaning due to possible condensation of heavy fractions of tar and significant carbon content which causes increase of electric conduction and reduction of dust removal efficiency (Stanghelle et al. 2007). Therefore a combination of cyclones with either ceramic or granular (sand) bed filters is recommended for high and medium temperature gas cleaning (Smid et al. 2005). But ceramic filters have insufficient mechanical strength and low thermal conductivity (Leibold et al. 2008). And according to Yang Gua-Hua and Zhou Jiang-Hua (2007), dual layer granular bed filters with bed particle sizes of $0.7 \mathrm{~mm}$ and $3 \mathrm{~mm}$ have higher dust collection capacity. Therefore, cyclone combined with dual layer granular bed filter has been selected here based on the above findings. The granular bed filters are also cheaper and more flexible for partly sticking particles. Temperatures lower than $600-650^{\circ} \mathrm{C}$ are recommended to remove alkali vapours with the dust particles.

\subsubsection{Based on removal efficiency}

According to the analysis given by Hasler et al. (1998) on the evaluation of gas cleaning technologies, the highest tar separation was found in catalytic tar crackers, venturi scrubbers and sand bed filters as shown in the Table 8.

Table 7 operating conditions and efficiency of some particle removal equipments (Guan et al. 2008)

\begin{tabular}{|l|l|l|l|}
\hline $\begin{array}{l}\text { Dust } \\
\text { separator }\end{array}$ & $\begin{array}{l}\text { Temperature } \\
\text { range }\left({ }^{\circ} \mathrm{C}\right)\end{array}$ & $\begin{array}{l}\text { De-dusting } \\
\text { efficiency }\end{array}$ & $\begin{array}{l}\text { Pressure } \\
\text { drop } \\
\text { (Kpa) }\end{array}$ \\
\hline cyclone & $100-900$ & Dust $>5 \mu \mathrm{m}, 80 \%$ & $<10$ \\
\hline $\begin{array}{l}\text { Fabric } \\
\text { bag } \\
\text { filters }\end{array}$ & $60-250$ & $\begin{array}{l}\text { Dust }>0.3 \mu \mathrm{m}, \\
99-99.8 \%\end{array}$ & $1-2.5$ \\
\hline $\begin{array}{l}\text { Wet } \\
\text { scrubbers } \\
\text { (venture) }\end{array}$ & $20-100$ & $\begin{array}{l}\text { Dust 0.1-1 } \mu \mathrm{m}, \\
85-95 \%, \\
\text { otherwise } 90- \\
99 \%\end{array}$ & $5-20$ \\
\hline $\begin{array}{l}\text { Fibrous } \\
\text { ceramic } \\
\text { filters }\end{array}$ & $200-800$ & $\begin{array}{l}\text { Dust }>0.3 \mu \mathrm{m}, \\
99-99.8 \%\end{array}$ & $1-2.5$ \\
\hline $\begin{array}{l}\text { Rigid } \\
\text { ceramic } \\
\text { filters }\end{array}$ & $200-800$ & $\begin{array}{l}\text { Dust }>0.1 \mu \mathrm{m}, \\
99.5-99.99 \%\end{array}$ & $1-5$ \\
\hline $\begin{array}{l}\text { Metallic } \\
\text { foam } \\
\text { filters }\end{array}$ & $200-800$ & $\begin{array}{l}\text { Dust }>1 \mu \mathrm{m}, 99- \\
99.5 \%\end{array}$ & $<1$ \\
\hline $\begin{array}{l}\text { Granular } \\
\text { bed } \\
\text { filters }\end{array}$ & $200-800$ & $\begin{array}{l}\text { Highly depends } \\
\text { on regime and } \\
\text { surface } \\
\text { filtration }\end{array}$ & $<10$ \\
\hline
\end{tabular}

Table 8 Particle, tar and trace components reduction in various gas cleaning systems (Hasler et al. 1998)

\begin{tabular}{|c|c|c|c|c|c|c|}
\hline $\begin{array}{l}\text { Cleaning } \\
\text { method }\end{array}$ & $\begin{array}{l}\text { T } \\
\left({ }^{\circ} \mathrm{C}\right)\end{array}$ & 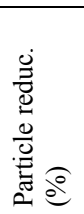 & 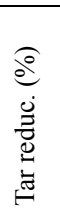 & 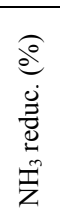 & 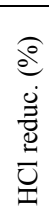 & 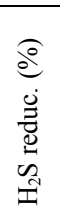 \\
\hline $\begin{array}{l}\text { Catalytic tar } \\
\text { cracker }\end{array}$ & 900 & & $>95$ & & & \\
\hline Fabric filter & 200 & $60-85$ & $\begin{array}{l}- \\
25- \\
0\end{array}$ & & & \\
\hline $\begin{array}{l}\text { Sand bed } \\
\text { filter }\end{array}$ & $\begin{array}{l}10- \\
20\end{array}$ & $70-95$ & $\begin{array}{l}60- \\
95\end{array}$ & $>95$ & 90 & $\begin{array}{l}80- \\
95\end{array}$ \\
\hline $\begin{array}{l}\text { Rotational } \\
\text { wash tower }\end{array}$ & $\begin{array}{l}50- \\
60\end{array}$ & $70-90$ & $\begin{array}{l}10- \\
25\end{array}$ & & & \\
\hline $\begin{array}{l}\text { Venture } \\
\text { scrubber }\end{array}$ & & & $\begin{array}{l}50- \\
90\end{array}$ & & & \\
\hline $\begin{array}{l}\text { Rotational } \\
\text { atomizer }\end{array}$ & $<100$ & $95-99$ & & & 90 & $>95$ \\
\hline $\begin{array}{l}\text { Wet } \\
\text { electrostatic } \\
\text { precipitator }\end{array}$ & $\begin{array}{l}40- \\
50\end{array}$ & $>99$ & $\begin{array}{l}0- \\
60\end{array}$ & & & \\
\hline
\end{tabular}

Catalytic cracking is used for large scale gasifiers and high temperature syngas with tar levels more than $10,000 \mathrm{mg} / \mathrm{Nm} 3$. But small scale fixed bed gasifiers have a syngas temperature in the range of 500 to $6000 \mathrm{C}$ and tar concentration lower than $1000 \mathrm{mg} / \mathrm{Nm} 3$. Therefore it will not be economically attractive to use this relatively expensive equipment for such low temperature and tar level and sand bed filter has been considered an option for this case. 


\subsubsection{Based on capital investment}

Hasler and Nussbaumer (1999) have compared the capital investment required for different gas cleaning technologies for a $300 \mathrm{~kW}$ fixed bed co-current gasifier as shown in the Table 9 below. The table is used here only to compare the different technologies and sand bed filter has the lowest capital investment. A water quench will be used in this case before the sand bed filter to cool the gas and compensate for the remaining removal efficiency.

Table 9 Expected particle and tar separation and investment cost of the gas cleaning for a $300 \mathrm{~kW}$ fixed bed biomass gasifier including waste treatment

\begin{tabular}{|l|l|l|l|}
\hline $\begin{array}{l}\text { Gas } \\
\text { cleaning (\%) }\end{array}$ & $\begin{array}{l}\text { Particle } \\
\text { sepration (\%) }\end{array}$ & $\begin{array}{l}\text { Tar } \\
\text { separation } \\
(\%)\end{array}$ & $\begin{array}{l}\text { Cost } \\
\text { kECU }\end{array}$ \\
\hline $\begin{array}{l}\text { Venture } \\
\text { scrubber }\end{array}$ & 95 & 60 & 115 \\
\hline $\begin{array}{l}\text { Sand bed } \\
\text { filter }\end{array}$ & 80 & 70 & 42 \\
\hline Wet ESP & 95 & 60 & 157 \\
\hline $\begin{array}{l}\text { RPS/tar } \\
\text { adsorber }\end{array}$ & 90 & 95 & 73 \\
\hline $\begin{array}{l}\text { Fabric } \\
\text { filter/tar } \\
\text { adsorber }\end{array}$ & 95 & 95 & 89 \\
\hline
\end{tabular}

\subsection{Process description and Flow sheet development}

According to the flow sheet developed in this paper for a $20 \mathrm{~kW}$ fixed bed gasifier, the synthesis gas will first be taken to a heat exchanger to be cooled from a temperature of approximately 600 to $450^{\circ} \mathrm{C}$. The heat recovered will be used to preheat the air used in the gasifier. This cooling also facilitates removal of alkali vapours with the dust particles. The temperature $450^{\circ} \mathrm{C}$ is choosen to avoid of condensation of $\operatorname{tar}\left(375-400^{\circ} \mathrm{C}\right)$ in the heat exchanger and cyclone. The cooled synthesis gas will then be fed to a cyclone which removes more that $80 \%$ of particles having diameter more than $5 \mu \mathrm{m}$. The reduction of the synthesis gas temperature to $450^{\circ} \mathrm{C}$ will also improve the separation efficiency of the cyclone in addition to decreasing the cost. Then the partially cleaned syngas from the cyclone will be quenched by water injection before it enters the sand bed filter. This facilitates removal of particle and tar in the sand bed filter besides removing some of it. The syngas will be cooled in the quench cooler from 450 to $250^{\circ} \mathrm{C}$ to condense some of the tar and keep the syngas temperature in the operating temperature range of sand bed filter. Finally it will be fed to a two stage sand bed filter. According to Hasler and Nussbaumer (1999), the clean gas will leave the dual lay sand bed filter at a temperature of 5 to $250 \mathrm{C}$. This can in practice be used directly in an IC engine since it operates at room temperature.

According to the Table 7 given in the process selection section, the cyclone can remove at least 80 of particles greater than $5 \mu \mathrm{m}$ in size. And from a particle size distribution chart given by Hasler and Nussbaumer (1999) for wood in a fixed bed gasifier, approximately
$42 \%$ of the particles have aerodynamic sizes greater than $5.49 \mu \mathrm{m}$. So the cyclone can remove roughly $33.6 \%$ of the particles from the syngas and the sand bed removes $80 \%$. This is more than the $90 \%$ removal requirement for an IC engine application. For the tar removal, the sand bed filter removes approximately $70 \%$ as shown in the Table 7 and the remaining $20 \%$ for an IC engine application can be removed during water quenching.

According to the Table 7, the cyclone can remove at least 80 of particles greater than $5 \mu \mathrm{m}$ in size. And from a particle size distribution chart given by Hasler and Nussbaumer (1999) for wood in a fixed bed gasifier, approximately $42 \%$ of the particles have aerodynamic sizes greater than $5.49 \mu \mathrm{m}$. So the cyclone can remove roughly $33.6 \%$ of the particles from the syngas and the sand bed removes $80 \%$. This is more than the $90 \%$ removal requirement for an IC engine application. For the tar removal, the sand bed filter removes approximately $70 \%$ as shown in the table. And the remaining $20 \%$ for an IC engine application can be removed during water quenching.

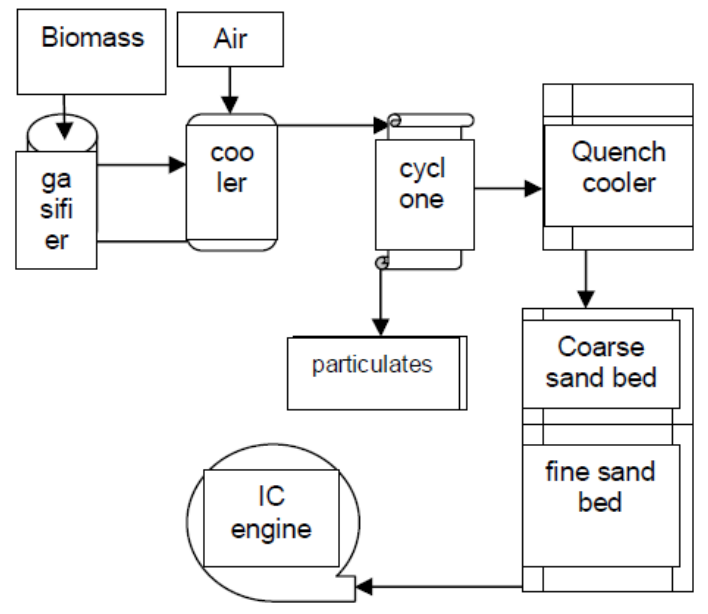

Fig. 3. Flow sheet developed

\section{Conclusions}

The present paper proposes an overview of existing processes to remove tarry products and particles from syngas produced in gazeifier. Syngas cleaning units were compared regarding their efficiency to reach gas quality requirement for use in internal combustion engines. A special emphasis on tar and particle removals from small scale gasifier was developed on the basis of treatment efficiency and economical costs. A treatment process flowsheet was then proposed consisting on cooler, cyclone, quench cooler and bed filter units.

\section{REFERENCES}

Hasler, P., and Th. Nussbaumer (1999). Gas cleaning for IC engine applications from fixed bed biomass gasification. Journal of Biomass and Bioenergy $16,385-395$.

Jun, H., and K. Heejoon (2008). The reduction and 
control technology of tar during biomass gasification/pyrolysis: An overview. Journal of Renewable and Sustainable Energy Reviews 12, 397-416.

McKendry, P. (2002). Energy production from biomass (part 3): gasification technologies. Journal of Bioresource Technology 83, 55-63.

Pratola, F., M.L. Pellizza, F. Repetto, E. Maggio, and C. Amorino (2002, October). Integration of biomass gasification in a gas-engine cogeneration system. International conference on clean coal technology for our future, Chia Laguna, Sardinia, Italy.

Thana, P., N. Tomoaki, and Y. Kunio (2010). Tar removal from biomass pyrolysis gas in two-step function of decomposition and adsorption. Journal of applied energy 87(7), 2203-2211.

Bain, R.L. (2007). World Biofuels Assessment; Worldwide Biomass Potential: Technology Characterizations (Milestone Report). NREL Report No. MP-510-42467, Golden, CO: National Renewable Energy Laboratory.

Ahrenfeldt, J. (2007, March). Characterization of Biomass Producer Gas as Fuel for Stationary Gas Engines in Combined Heat and Power Production. Ph.D. Thesis, Technical University of Denmark, Denmark.

Dale, N.K., R. Simbeck, J. Donald, Wilhelm (2002, December). Process screening analysis of alternative gas treating and sulphur removal for Gasigfication. U.S. Department of Energy, National Energy Technology Laboratory Report, SFA Pacific, Inc.

Sundac, N. (2007, September). Catalytic cracking of tar from biomass Gasification. Department of Chemical Engineering, Lund University, Sweden.

Hernelind, M., and B. Gevert (2002). Hydrotreatment of tar formed in gasification of biomass. Department of Applied Surface Chemistry, Chalmers University of Technology, Sweden.

Dayton, D. (December 2002). A Review of the Literature on Catalytic Biomass Tar Destruction. NREL Report No. TP-510-32815, US National Renewable Energy Laboratory.

Seung, J.L., H.K. Soung, H.K. Kyoung, D.Y. Young, Y. Yun (2007). Development of a pilot-scale acid gas removal system for coal syngas. Korean $J$. Chem. Eng. 24 (6), 1128-1132.

Lettner, F., H. Timmerer, P. Haselbacher (2007, December). Biomass gasification - State of the art description. Intelligent Energy - Europe (IEE) EIE/06/078/SI2.447511, Graz University of Technology - Institute of Thermal Engineering.

Mustafa, B., B. Mehmet, K. Elif, and B. Havva (2009).
Main routes for the thermo-conversion of biomass into fuels and chemicals Part 2: Gasification systems. Journal of Energy Conversion and Management 50, 3158-3168.

Baratieri, M., P. Baggio, B. Bosio, M. Grigiante, and G.A. Longo (2009). The use of biomass syngas in IC engines and CCGT plants: A comparative analysis. Journal of Applied Thermal Engineering, 29, 3309-3318.

Knoef, H.A.M. (2000). A review of fixed bed gasification systems for biomass. School of energy studies for agriculture, India.

Maniatisa, K., and A.A.C.M. Beenackers (2000). Tar Protocols. IEA Bioenergy Gasification Task. Journal of Biomass and Bioenergy 18, 1-4.

Jun, H., and K. Heejoon (2008). The reduction and control technology of tar during biomass gasification/pyrolysis: An overview. Journal of Renewable and Sustainable Energy Reviews, 12 (2), 397-416.

Hasler, Ph.B., and R. Nussbaumer (1997). Evaluation of gas cleaning technologies for small scale biomass gasifiers. Swiss federal office of energy.

Li, X.T., J.R. Grace, C.J. Lim, A.P. Watkinson, H.P. Chen, and J.R. Kim (2004). Biomass gasification in a circulating fluidized bed. Biomass and Bioenergy 26, 171-193.

Bridgwater, A.V. (1994, July). The technical and economical feasibility of biomass gasification in power generation. Energy Research Group, Aston University, Birmingham.

Jansen, J.C., K. Jönsson and La.M. Hagman (2002). Biological detoxification of tar-water. Water Sci Technology 46, 67-76.

Boerrigter, H. (2005). "OLGA” tar removal technology; The Energy research Centre of the Netherlands. ECN.

NarvPaez, I., and A. Orpso (1996). Biomass gasification with air in an atmospheric bubbling fluidized bed. Effect of six operational variables on the quality of produced raw gas. Ind Eng Chem Res 35, 2110-2120.

Ding, X. (2003). Catalytic Decomposition of Ammonia in Producer Gas. The dissertation of Zheng zhou University, China.

Dayton, D. (2002). A review of the literature on catalytic biomass tar destruction. National Renewable Energy Laboratory, USA.

Paasen, S.V.B. (2004). Tar formation in fluidized-bed gasification - impact of gasifier operating conditions. The 2nd world conference and technology exhibition on biomass for energy, industry and climate protection, Rome, Italy. 
L.C. Laurence and D. Ashenafi / JAFM, Vol. 5, No.1, pp. 95-103, 2012.

Reed, T.B., and Das, A. (1994). Handbook of Biomass Downdraft Gasifier Engine Systems. Biomass Energy Foundation Press.

Smid, J., S.S. Hsiau, C.Y. Peng, H.T. Lee (2005). Granular moving bed filters and adsorbers. Advanced Powder Technol. 16 (4), 301-345.

Stanghelle, D., T. Slungaard, and O.K. Sonju (2007). Granular bed filtration of high temperature biomass gasification gas. J. of Hazardous Materials 144(3), 668-672.

Leibold, H., A. Hornung, and H. Seifert (2008). HTHP syngas cleaning concept of two stage biomass Gasification for FT synthesis. Powder Technol. $180,265-270$

Kosstrin, H. (1980). Direct formation of pyrolysis oil from biomass. In: Proceedings specialists workshop on fast pyrolysis of biomass, SERI/CP622-1096, 105-121. 